\title{
Teachers' Challenges in Teaching English Writing Skills for Visually Impaired Students at Indonesian Special Senior High Schools
}

\author{
Prih Febtiningsih ${ }^{1)}$ Ardiya $^{2)}$, Agung Prasetyo Wibowo ${ }^{3)}$ \\ ${ }^{123}$ Universitas Muhammadiyah Riau, Pekanbaru. Indonesia \\ lemail: prihfebtiningsih@umri.ac.id \\ 2email: ardiya@umri.ac.id \\ 3email: agungprasetyo.w@umri.ac.id
}

\begin{abstract}
:
Teaching English at Indonesian special senior high schools is applied based on the curriculum determined by the government. However, there were some problems found in English language teaching for visually impaired students especially in writing. This research aimed to investigate the teachers' challenges in teaching English writing for visually impaired students. The respondents were taken purposively, namely the English teachers at Indonesian special senior high schools for visually impaired students namely SLB Sri Mujinab, SLB Negeri Pembina and SLB Kasih Ibu. The data for the research were collected from semi-structured interview conducted to get specific information about what challenges encountered by the English teachers teaching writing skills for students with visual impairment. The challenges encountered by the teachers in teaching writing were inappropriateness of curriculum and syllabus with the students' need, time constraint of teaching, lack of learning media, lack of teaching strategy, inappropriateness of teacher's qualification, and students' attitude problem. These challenges made the teachers difficult in teaching English writing.
\end{abstract}

Keywords: Teaching Writing, Visual Impairment, Teachers' Challenges, English Language Teaching

\section{INTRODUCTION}

Students with visual impairment are categorized into three basic condition, fully blind which defines a condition of individual with no chance to function their vision; low vision described as having low light perception, still having the capability to function the eyes; and distorted vision identified with the disease such achromatism, photophobia, or not centralized vision (Kelly, 2019; Hayhoe, 2012). However, Indonesia Special School for Visual Impairment accounts two basic impairment, fully blind and low vision. These students currently receive educational service from government to study either in special school for visual ELT- Lectura, Vol 8, No 1, February 2021 impairment or inclusive school (Zahrinai, 2017). Special Schools for Visual Impairment in Indonesia has been securely provided by Indonesia Education Department along with other special schools facilitating students with different needs and disability (Indonesia Ministry of Education and Culture, 2014). Besides, the educational act demonstrates the feasibility of the document to support inclusivity in which students with all background needs and disability are welcomed and possible to experience educational process with other students who are not identified to possess certain needs and disability, following with sources which can be used by teachers and students in inclusive schools (Rizky, 2014). 
This suggests that Indonesia supports the values of inclusiveness and securely protect students' rights of receiving equal opportunities in studying at schools. However, Zahrinai (2017) found that the evaluation of facilities provided by the government for students with disability shows a dramatic condition, where the inappropriate building and similar facilities with mainstream schools were found. The national standards regarding the provision of educational facilities for visually impaired students to the design criteria for the provision of educational facilities for the disabled as a whole are at the level of 'inappropriate' or 'less achieved' with the proportion of achievement, 59.25\% (Ibid, 2017; Rahayu \& Dewi, 2013). Given that, this eventually opens up a new issue that the implication of such provision is still inadequate and needs to be taken into account.

Concerning the issue of impracticality of such laws, students with visual impairment struggle to acquire knowledge in English lesson. Susanto and Nanda (2018) found that English teachers are less qualified in teaching respective students since the process of teaching for respective students requires special treatment. Mangal (2007) claimed that education for blind people requires special attention and provision of education due to the difficulties and deficiencies which make them different from children who have normal vision. It is also important to note that the applied education curriculum should not only anticipate inclusive behavior, conditions and processes compared to exclusive partners (Nugent, 2018), but also increase students' access to learning and social opportunities (Whitburn, 2014). Araluce (2005) argues that the curriculum material in schools is urged be changed to suit social and pedagogical lives of students who have visual impairments, and recommends that teachers accept the condition as they are and try to realize their potential, personality, and interests. Changes to curriculum materials and teaching methods for blind students are believed to be able to attract students who have normal vision also due to variations in the methods and teaching materials applied. Susanto and Nanda (2018) consider that although visual impaired students receive inadequate teaching in learning foreign languages, they use various resources with Screen Reader technology such as Non-Visual Desktop Access (NVDA) and Job Access with Speech (JAWS). In addition, they can learn languages with role-play pedagogy and musical instruments as well. This finding suggests that blind students can actually have a unique way of learning a foreign language and this ability should be recognized to gain the perspective of students who have received special needs and disability education.

There are several studies conducted by researchers relating to the teaching of English to blind students. Agesa (2014) in her research entitled "Challenges Faced by Learners with Visual Impairments in Inclusive Settings in Trans-Nzoia County" examines the challenges faced by blind students in inclusive settings. This study concludes that it is difficult for most teachers to plan for these students to be appropriate for their academic needs. Most respected students are placed in inclusive schools without specially trained teachers to handle technical fields like Braille. Students with visual impairments do not have the support of educational stakeholders, therefore, are withdrawn when placed in inclusive conditions. On the other hand, Basaran (2012) conducted a case study titled "Teaching English to visually impaired students in Turkey: A case study" which focused on strengths and challenges as well as the techniques and materials used by three EFL teachers working in two special primary schools for the visually impaired. Analysis of observational data and interviews found several themes problems such as disturbances, problems 
related to the family, curriculum, verbalism, scarcity of resources, and the usual use of traditional grammar-translation techniques by teachers. Some implications such as the need for inclusion of visually impaired problems in formal EFL teacher training, development of techniques and EFL teaching materials specifically for visually impaired and establishing inclusive settings with visually impaired students and students with normal vision are suggested. Furthermore, Kocyigit and Artar (2015) in their study entitled "A challenge: Teaching English to visually-impaired learners" found that teachers taught with their own techniques through trial and error and unfortunately did not receive adequate academic and pedagogical guidance from outside sources. They should rely on their own intuition in making decisions about the learning process and often cannot vary the techniques and methods they use in their classrooms, to meet the needs of respective students.

Regarding the challenges faced by the teachers, previous studies have shown that most of the teachers had difficulties in teaching techniques, curriculum and also from the students' situation problem in teaching English so that the students could not receive adequate and appropriate needs for their academic. These previous researches were conducted to see the teachers' challenges in teaching English as a whole. While, the current research was conducted to find out the teachers' challenges in teaching English writing skill for visually impaired students since writing is a skill that has a high level of difficulty and complexity in English. This is because in writing, students are expected to be able to explore and convey ideas in good and correct English. This research contributes as information and knowledge for the teachers as well as the governmental officers to notice the challenges faced by the teachers in teaching visually impaired students' writing skill.
Given that, this research focuses on answering a research question "What are the Indonesian teachers' challenges in teaching visually impaired students' writing skills?

\section{METHOD}

This research deployed a qualitative method to seek the challenges experienced by English teachers teaching writing skills for Indonesian visually impaired students at Indonesian Special or Inclusive Senior High Schools. Six English teachers from Indonesia Special Senior High Schools for Visual Impairment were purposively selected as the participants of this study. The data for the research were collected from semi-structured interview conducted to get specific information about what challenges encountered by the English teachers teaching writing skills for students with visual impairment. The questions were adopted from Basaran (2012) and Bishaw (2012) consisting of 13 questions related to challenges in English language teaching, precisely in writing skills. Before the questions were given to the respondents, they had been validated by two senior lecturers, experts in English language teaching from two reputable universities. The collected data were analyzed by using descriptive qualitative. The results of interview were classified based on the research question. The data were analyzed through transcription. Analysis of the results of the transcription was then carried out interpretation, the process by which researchers compared the results of previous studies with the findings in this study. In other words, the thematic analysis was carried out by using the concept of codes and themes of the questions to be answered from this research. The names of the respondents did not appear in the process of transcription and interpretation in this research. 


\section{FINDINGS AND DISCUSION 3.1 Findings}

This research was a qualitative research which used interview as intrument to take the data. After being conducted a research from interview with six teachers at three Indonesian Special or Inclusive Senior High Schools, it was obtained that there were some challenges of the teachers in teaching English writing for Indonesian visually impaired students. The challenges could be seen as follows:

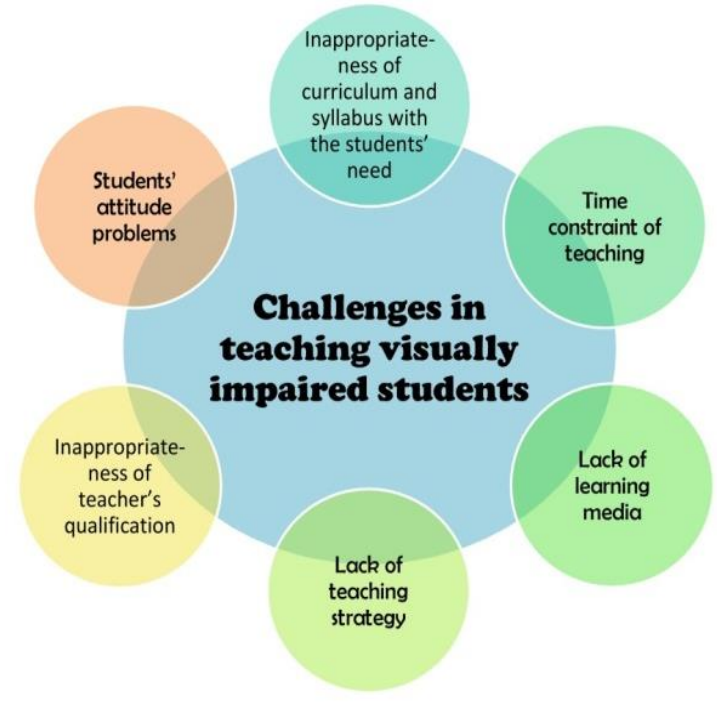

Figure 1. Challenges in Teaching Visually Impaired Students

Based on the interview result described above, the first challenges appeared from the curriculum and syllabus applied. The curriculum and syllabus determined by the government in teaching english writing for visually impaired students was not suitable with the students' need so that the teachers had to modify the appropriate material to the students' need. Second, the inadequate time for teaching the students especially teaching writing also became a challenge for teachers, only once in a week ( $2 \times 50$ minutes). This triggered the teacher ineffectively taught the students who still had problems in writing.

Third, the lack of supporting learning media was also another challenge for teachers in teaching the visually impaired students, in writing particularly such as audio provision (speaker) and reading tool (Braille/Reglet). The teachers only used Cellular phone or Laptop to convey the learning material. Fourth, the teaching strategy used by the teachers was still conventional. They only mentioned the English words letter by letter and their students wrote them directly. Fifth, some of the teachers' education background were from English education and some were from special education. The teachers graduated from English education had difficulty in teaching English especially writing because they had limited knowledge in reading Braille. Otherwise, the teachers graduated from Special education also had problem in delivering the material because they didn't master English.

Sixth, the students' attitude problems also became the teachers' challenge in teaching English writing. Several students still complained that English was difficult thing to be acquired due to the distinctive reading and writing ways. Besides, they must be accompanied in writing by their teachers. If they were not accompanied by their teachers, they would not want to do writing.

\section{Inappropriateness of Curriculum and Syllabus with the Students' Need}

Based on the interview result, teachers' challenge to teach writing is due to curriculum and syllabus content. The curriculum and syllabus provided by the government is considered to be inappropriate with the students' needs. This leads to the modification of the material which should be adjusted with students' needs. As a claim is stated that:

".... It is hard to adjust with the system from the government. I would prefer to modify the content and adjust with the needs of the students. It is impossible if we as teachers 
have to stick with all the things decided from the curriculum."

Also, another teacher pointed out that:

"I have been working here in the school for more than a decade. What I've seen in the classroom is somehow different from the context that we have to teach or follow from the syllabus. It is hard to believe that if I have to follow $100 \%$ from the government, our students just cannot follow the lesson and eventually it might impact the unachieved learning objectives or fail."

\section{Time Constraint of Teaching}

Moreover, the inadequate allocation of time for teaching writing also is another thing to be concerned about as a challenge for teachers; once in a week $(2 \times 50$ minutes). It is claimed to be insufficient and ineffective for the teaching and learning process. A teacher mentioned that:

"It cannot be denied that teaching writing in one meeting once a week would improve students' skill in writing. It is not only writing, but also other skills."

One teacher is convinced that language needs to be applied or implemented on a daily basis. As perceived that:

"It is a need for students to have further assistance from parents or the school environment to develop their skill in writing. If it is only at school which is once a week, I don't think their skill would improve."

"We just have one meeting every meeting, and it's only 2 sessions in which each session runs for about 40 to 50 minutes. I wish I could allocate more sessions every week."

\section{Lack of Learning Media}

It is found that supporting learning media is also another challenge for teachers in teaching the visually impaired students, in writing particularly such as audio provision (speaker) and reading tool (Braille/Reglet). The teachers only used Cellular phone or Laptop to convey the learning material. It is mentioned that:

"During teaching and learning activities in the classroom, I only rely on audio listening from my phone, then I share the audio via loudspeaker to the students."

"Teaching students how to write correct English spelling by using audio or recording via laptop or computer would be good, unfortunately, we don't have it here. I use my own phone to support the activity instead and I know this is not efficient."

Another claim is the challenge of using reglet:

“.... students use reglet in writing, a kind of tool that helps them in writing Braille letters. So, they do not write the same as we write, either in English or in Bahasa."

"They write everything by using reglet, so after they complete their writing, we as a teacher will read that not in alphabets, but in Braille. I am personally able to read, but the problem is that not all students are able to use reglet, and sometimes their writing after using reglet is still messy that we eventually cannot read."

“... further assistance is also needed, so I have to handle them one by one. This wastes time." 
These findings suggest that the challenge of teaching writing would likely be the lack of technological sources and supports. Students' ability in writing by using reglet is taken into account. It cannot be denied that the inadequate teaching tool or technology is still one of the many concerns that the educational practitioners and professionals experience. This would therefore end up with the unachieved learning objectives.

\section{Lack of Teaching Strategy}

In addition, lack of teaching strategy is assumed to challenge teachers in teaching writing. Given that this issue is linked with teacher professional development from schools which ideally contribute to the betterment of learning outcomes. The claim was made through the limited number of teaching strategy adopted in the classroom such as dictation by stating:

"What I always do in the classroom is that I dictate the words, and they write the words directly."

"I am still figuring out what exactly the most suitable methods in teaching writing, what I can do to contribute to students' writing activity in the classroom is by mentioning the words and ask them to write by using riglet"

“.... I've never had any training in teaching English, especially in writing for blind students, so dictation to improve students' writing would be suitable"

\section{Inappropriateness of Teachers' Qualification}

On the other hand, teachers' qualification is considered to be another issue which challenged them in teaching writing. Some teachers hold English language teaching degrees with no experience in teaching students with special needs and disability, whilst the remainings were graduated from special educational needs and disability departments having lack knowledge in teaching English.

"To be honest, I am from English education study program. It's out of my expectation that I would work here, it is apparently difficult to teach students with disabilities."

"I graduated from English education, but I have no idea how to teach students with special conditions or disabilities, it's my first experience, so I have to learn how to teach them."

"I have been working here for quite a long, moreover I graduated from Special Educational Needs and Disability study program. Never I have in my mind that I have to teach English now, it's a new subject that I still have to deepen, no one at the school could contribute to teach this subject."

\section{Students' Attitude Problem}

Finally, students' attitude inhibits them from teaching English writing. Several students still complained that English was difficult to be acquired due to the distinctive reading and writing ways. Besides, they must be accompanied in writing by their teachers. If they were not accompanied by their teachers, they would not want to do writing.

"English is not a difficult subject, but when I just want to start the lesson, the students suddenly claim it was difficult and begging for another lesson."

"I found it hard to handle the class, because every single student will study if there's personal guidance. If 
I don't approach them individually, they will not work the assignment."

\subsection{Discussion}

The finding of the study shows numerous data depicting many challenges that the teachers encountered in teaching writing skills for students with visual impairment conditions. As It is stated in the research question that the study is willingly to investigate:

What are the challenges encountered by the teachers in teaching English writing skills for visually impaired students?

There are several challenges encountered by the teachers in teaching writing for visually impaired students. As it is firstly found that curriculum and syllabus designed by the government entails the teachers to modify the content, hence the context of teaching and learning is ideally based on the students' need, not following what the curriculum and syllabus offered. This finding is surprisingly linked with the same finding from a case study in Turkey that Kocyigit and Artar (2015) pointed out that content of the material provided challenged the teachers to provide teaching and learning activities. It is still a line with the obstacles experienced by the teachers in the respective country that insufficient time allocation was another issue which inhibited teachers from teaching and training students' skills in writing. This time allocation allotted in the teaching and learning writing within the respective schools in this study shows that similarities from the previous study. This confirms that teaching writing skills for the visually impaired need extra time and insufficient amount

of time would ideally challenge the teachers to provide an efficient learning process.

Furthermore, this study finds that providing appropriate teaching strategies in teaching writing skills for visually impaired students is a significant issue which confirms that teachers in the respective schools need training which could enhance and improve their competency in teaching. Dea and Negassa (2019) identified that several challenges encountered by teachers in Ethiopia in teaching students with visual impairment are reflected from the availability of professional training or teacher development programs as well as the existence of learning sources which ideally contribute to support the teaching and learning process (Basaran, 2012).

However, two surprising challenges that the teachers in this research encountered can be seen from the issue of teacher qualification and students' attitude. Having qualification in English language teaching but no experience in teaching visual impaired students or graduated from special needs and disability study with no prior or sufficient knowledge in teaching English is one striking problem which challenges the teachers teaching in the schools. Kapur (2018) found that qualified human resources is a significant factor which contributes to the successful learning process in the classroom. Finally, students' attitude which frequently shows a refusion from studying with the teacher is an obvious challenge that the teachers should ideally overcome. Al-Busaidi and Tuzlukova (2018), and Holdheide et al (2010) state that evaluation of teachers' practice counts for a call for a revision. This indicates that teachers should be able to adjust with students' behaviour and appropriate treatment is considered to be a motivation for the students to be active and willing to participate in classroom activity.

From the findings above, it is important to know that education for impaired students requires special attention and provision of education due to the difficulties and deficiencies which make them different from children who have normal vision. It is also important to note that the applied education curriculum should not only anticipate inclusive behavior, conditions and processes compared to exclusive partners (Nugent, 2018), but also increase students' access to 
learning and social opportunities (Whitburn, 2014).

\section{CONCLUSION}

The result of this research found that the teachers encountered some challenges in teaching English writing skills for Indonesian visually impaired students at Indonesian special senior high schools. The challenges were from curriculum and syllabus content, time allocation, learning media, teaching strategy, teacher's qualification, and students' attitude. These make the teachers difficult in delivering the writing material so that some students also could not receive the material well. It is suggested that the candidate teachers who want to teach at inclusive senior high schools should follow the extra training related to impairment students. The teachers who have English education background should take the training about visual impairment. Otherwise, the teachers who have special need education background also should join the English teaching training. This aims to make the teaching learning process for visually impaired students can run well and maximally.

\section{REFERENCES}

Agesa, L. (2014). Challenges faced by learners with visual impairments in inclusive setting in Trans-Nzoia County. Journal of Education and Practice, 5 (29): 185-192

Al-Busaidi, S., \& Tuzlukova, V. (2018). Teachers' Perceptions of Practices and Challenges of Innovating for the Inclusion of Special Needs University English Language Learners in Oman. Journal of Educational and Psychological Studies [JEPS] , 12 (4), 659-671.

Araluce, H. A. (2005). Teaching English to Blind and Visually Impaired Young Learners: the Affective Factor. Unpublished Doctoral dissertation. Spain. Retrieved from http://www.scribd.com/doc/63003758 /189-Teaching-English.

Başaran, S. (2012). Teaching English to visually impaired students in Turkey: A case study. Energy Education Science and Technology Part B: Social and Educational Studies, 2012 (217226), 11.

Bishaw (2012). Teaching English to the Students with Difficulties in Inclusive Settings.

http://www.academia.edu/2604749/In clusive_Teaching_in_the_Context_of _English_Language_Teaching_ELT_ 14.3517 November 2017.

Dea, P., \& Negassa, D. (2019). The Influence of Demographic Factors on Teachers' Instructional Practices and Challenges in Including Students with Visual Impairment in Government Secondary Schools of Harari Region. International Journal of Education and Literacy Studies, 7(3), 19. 
https://doi.org/10.7575/aiac.ijels.v.7n. 3p.19.

Hayhoe, S. (2012). What is visual impairment? National HE STEM Programme.

Holdheide, L. R., Goe, L., Croft, A., \& Reschly, D. J. (2010). Challenges in Evaluating Special Education Teachers and English Language Learner Specialists. Research \& Policy Brief. National Comprehensive Center for Teacher Quality.

Indonesia Ministry of Education and Culture (2014). Peraturan Menteri Pendidikan Dan Kebudayaan Republik Indonesia Nomor 157 Tahun 2014 tentang Kurikulum Pendidikan Khusus.

Kapur, R. (2018). Factors influencing the students academic performance in secondary schools in India. University Of Delhi.

Kelly, S. M. (2019). Special Education Transition Services for Students with Visual Impairments. In Special Education Transition Services for Students with Disabilities. Emerald Publishing Limited.

Kocyigit, N., \& Artar, P. S. (2015). A Challenge: Teaching English to Visually-impaired Learners. Procedia - Social and Behavioral Sciences, 199(August), 689-694. https://doi.org/10.1016/j.sbspro.2015. 07.599 .

Mangal, S. K. (2007). Educating exceptional children: An introduction to special education.New Delhi, Prentice-Hall of India Private Ltd.

Nugent, M. (2018). Reframing inclusion: An exclusive-inclusive approach.
British Journal of Special Education, 45(2), 141-156.

Rahayu, S., \& Dewi, U. (2013). Pelayanan Publik Bagi Pemenuhan Hak-Hak Disabilitas di Kota Yogyakarta. NATAPRAJA, 1(1).

Rizky, U. F. (2014). Identifikasi Kebutuhan Siswa Penyandang Disabilitas Pasca Sekolah Menengah Atas. IJDS: Indonesian Journal of Disability Studies, 1(1).

Susanto, S., \& Nanda, D. S. (2018). Teaching and learning English for visually impaired students: an ethnographic case study. English Review: Journal of English Education, 7(1), 83-92.

Whitburn, B. (2014). Accessibility and autonomy preconditions to "our"e inclusion: A grounded theory study of the experiences of secondary students with vision impairment. Journal of Research in Special Educational Needs, 14(1), 3-15.

Zahrinai, F. D. (2017). Evaluasi Standar Fasilitas Pendidikan bagi Difabel Tunanetra (Doctoral dissertation, Universitas Pendidikan Indonesia). 